\title{
Gas SF 6 (Sulfur Hexa Fluorida) Sebagai Pemadam Busur Api Pada Pemutus Tenaga (PMT) Di Saluran Transmisi Tegangan Tinggi
}

\author{
Iman Setiono \\ Program Studi Teknik Elektro, Departemen Teknologi Industri, Sekolah Vokasi, Universitas Diponegoro \\ Jl. Prof. Soedarto SH, Tembalang, Semarang, Indonesia, 50275 \\ Email : imansetionoms@gmail.com
}

\begin{abstract}
Abstrak
Keberadaan Pemutus Tenaga (PMT) pada saluran transmisi mutlak diperlukan, karena untuk menyalurkan dan memutuskan sistem penyaluran tenaga listrik dari pusat pembangkitan sampai ke konsumen harus bisa di atur dengan menggunakan PMT ini. PMT adalah sebuah alat yang berfungsi untuk memutus-hubungkan aliraan listrik yang melalui saluran transmisi tegangan tinggi. Karena faktor tegangan tinggi, yaitu untuk Saluran Udara Tegangan Tinggi (SUTT) adalah 150 KV dan untuk Saluran Udara Tegangan Extra Tinggi (SUTET) adalah $500 \mathrm{KV}$, maka setiap kali menghubungkan dan memutuskan kontak di dalam PMT gesekan pada kontak-kontak tersebut yang terbuat dari logam. Akibat dari gesekan ini akan muncul bunga api yang sangat berbahaya dapat menimbulkan kebakaran dan kerusakan peralatan. Untuk memadamkan bunga api ini, maka di gunakan gas SF6 yang bersifat isolator, sehingga bunga api padam dan dapat mencegah terjadinya kebakaran dan kerusakan peralatan.
\end{abstract}

Kata kunci : Bunga api, Gas SF6, Pemutus tenaga, Tegangan tinggi.

\begin{abstract}
Gas SF6 (Hexa Fluoride Sulfur) As Fire Extinguisher On Power Breaker (PMT) On High Voltage Transmission Channel

The existence of Power Circuit breaker (PMT) in the transmission line is absolutely necessary, because to channel and decide the system of electricity distribution from the power station to the consumer must be managed by using this PMT. PMT is a device that serves to break-up the electricity supply through high voltage transmission lines. Due to the high voltage factor, that is for High Voltage transmission line (SUTT) is $150 \mathrm{KV}$ and for Extra High Voltage Transmission line (SUTET) is $500 \mathrm{KV}$, then every time connect and disconnect the contact inside the friction PMT on those contacts made from metal. As a result of this friction will appear very dangerous sparks can cause fire and equipment damage. To extinguish this spark, then in use SF6 gas that is an isolator, so the sparks out and can prevent the occurrence of fire and equipment damage.
\end{abstract}

Keywords: Spark, Gas SF6, Power Circuit breaker, High Voltage.

\section{PENDAHULUAN}

Pemutus tenaga listrik (PMT) adalah peralatan yang lazim terdapat pada gardu induk tegangan tinggi. Peranan PMT ini sangat penting karena berfungsi untuk memutus hubungkan rangkaian penyaluran daya listrik dari pusat pembangkitan ke konsumen serta sekaligus sebagai bagian dari sistem proteksi. Berbagai jenis PMT dilihat dari sisi peredam busur apinya ada empat dan salah satunya adalah yang menggunakan gas SF6. Peran peredam busur api 
sangat penting karena tanpa peredam, maka busur api yang timbul sebagai akibat dari adanya tegangan tinggi akan merusakan sistem, oleh karena itu mempelajari dan memahami PMT dengan peredam ini, sangat diperlukan bagi para pembaca yang berkecimpung didunia kelistrikan.

Keandalan sistem penyaluran tenaga listrik yang diharapkan, ternyata belum sepenuhnya dapat dipenuhi. Berbagai faktor sangat mempengaruhi kelangsungan penyaluran tenaga litrik ini, baik faktor alam maupun teknis lainnya. Hal ini dapat dimengerti karena sistem penyaluran tenaga listrik yang selama ini diterapkan di Indonesia masih kebanyakan menggunakan sistem saluran udara, sehingga kerawanan banyak terjadi yang menyebabkan terganggunya penyaluran tenaga listrik tersebut.

\section{GAS SF6}

Gas SF6 merupakan salah satu media isolasi yang baik, dapat berfungsi sebagai penyekat antara bagian bertegangan dengan ground hanya dengan jarak yang sangat pendek jika di bandingkan dengan isolasi udara. Selain itu jika terjadi percikan api / busur api pada peralatan yang di isolasi gas SF6, maka gas tersebut akan berfungsi sebagai pemadam busur api, sehingga tidak terjadi kerusakan yang lebih parah pada peralatan tersebut. (Adieliveline,2013).

\section{Sifat-sifat Fisik}

SF6 yang murni adalah tidak berwarna, tidak berbau, tidak beracun dan tidak mudah tercampur. Berat jenis SF6 pada temperatur $200 \mathrm{C}$ dan pada tekanan $760 \mathrm{mmHg}$ adalah $6,135 \mathrm{~kg} / \mathrm{m} 3$. Jika dibandingkan dengan berat jenis udara adalah lima kalinya.

Gas ini akan mencair pada temperatur yang rendah, temperatur pencairan bergantung pada tekanan yang diberikan. Pada temperatur $100 \mathrm{C}$ dan tekanan 15 atm, gas akan mencair. Jika tekanan gas ini tinggi, temperatur pencairan tinggi. Biasanya tekanan yang digunakan pada pemutus tenaga tegangan menengah adalah 7 bar (kopling galvanic/cm2). Dengan tekanan sebesar itu, kekuatan dielektrik menjadi besar sehingga dapat menahan tegangan transien yang terjadi pada waktu pembukaan kontak-kontaknya.

\section{Sifat-sifat Dielektrik SF6}

Kekuatan dielektrik SF6 adalah 5 kali kekuatan dielektrik udara pada tekanan beberapa atmosphere. Kekuatan dielektrik unsur gas ini akan bertambah besar menurut tekanannya.

\section{Sifat-sifat Kimiawi SF6}

Di dalam sebuah molekul SF6, atom sulfurnya terdapat pada daerah valensi tertinggi dari daerah valensi molekulnya. Sedangkan keenam ikatan molekulnya ialah kovalen, yang mana ini merupakan kelebihan dari molekul ini yang stabil. Susunan molekul dari SF6 merupakan bidang delapan yang pada keenam sudutnya ditempati atom fluoride.

SF6 adalah gas yang tidak mempunyai sifat kimia yang aktif sampai di atas $1500 \mathrm{C}$ dan tidak akan merusak logam, plastik dan bahan lain yang biasa digunakan pada komponen pemutus tenaga. Hal ini dapat dibuktikan dengan memanaskan gas tersebut sampai 5000C tanpa terjadi penguraian. Pada temperatur tinggi yang disebabkan oleh busur api listrik, gas akan terurai dalam beberapa unsur, yaitu SF2 dan SF4 dalam jumlah yang kecil dan unsur-unsur $S 2, F 2, S$, F. Bila unsur SF2 ini bereaksi dengan air, akan membentuk unsur hydrogen fluoride yang mempunyai sifat korosif terhadap porcelain. Semua unsur yang terurai akan berkombinasi kembali menjadi unsur SF6 seperti semula setelah temperaturnya turun. Unsur SF6 yang murni terdiri dari $21,95 \%$ sulfur dan $78,05 \%$ fluoride.Atom fluoride mempunyai sifat elektronegatif, dan ini berfungsi untuk menangkap elektron bebas ke bentuk muatan ion yang negatif, yang tidak dapat digunakan sebagai pembawa arus. Sifat elektronegatif ini menyebabkan waktu pembusuran pendek, kekuatan dielektrik dengan cepat dapat terbentuk. Kestabilan yang tinggi dari gas ini disebabkan enam ikatan kovalen dari molekul-molekulnya. Di samping itu, ikatan ini berada diantara atom sulfur, sedangkan enam atom fluoride membentuk suatu bangun octahedron. Karena unsur SF6 tidak mempunyai sifat kimia yang aktif, maka akan sangat menguntungkan bila dipakai pada pemutus tenaga tegangan menengah. Bagian-bagian logam dan kontak-kontak yang dialiri arus dalam unsur SF6 tidak akan rusak. 


\section{Unsur-unsur kimia dalam gas SF 6}

Unsur-unsur kimia yang terkandung dan tingkat kemurnian pada Gas SF6 antara lain adalah :

1.Carbon tetrafluoride ( CF4) $0,03 \%$

2. Oxygen + nitrogen ( air ) 0,03

3. Water 15 ppmM SF6 : $99,9 \%$

4. $\mathrm{CO} 2$ traces

5. HF 0,3ppmM

\section{PMT (PEMUTUS TENAGA )}

PMT (Pemutus Tenaga ) adalah suatu peralatan pemutus rangkaian listrik pada suatu sistem

Penyaluran tenaga listrik, yang dapat membuka dan menutup pada kondisi berbeban dan hubung singkat, juga kondisi tegangan normal maupun tidak normal.

Syarat yang harus dipenuhi oleh PMT antara lain :

1. Mampu menyalurkan arus maksimum sistem secara terus menerus

2. Mampu memutuskan dan menutup jaringan dalam keadaan berbeban maupun hubung singkat tanpa menimbulkan kerusakan.

3. Dapat memutuskan arus hubung singkat dengan kecepatan tinggi agar arus hubung singkat tidak sampai merusak peralatan sistem.

\section{Klassifikasi PMT}

Klasifikasi PMT berdasarkan media insulator dan material dielektriknya, dibagi menjadi empat jenis yaitu

\section{PMT minyak}

PMT minyak digunakan unutuk besaran arus sampai dengan $10 \mathrm{KA}$ pada tegangan 500 KV.Pada saat terjadi pemutusan kontak, busur api akan terjadi dalam minyak,akibatnya minyak akan menguap dan timbul gelembung gas yang menyelubungi busur api. Akibat panas dari busur api minyak mengalami dekomposisi dan menghasilkan gas Hydrogen yang bersifat menghambat produksi ion. Oleh karena itu, pemadaman busur api tergantung pada pemanjangan dan pendinginan busur api dan juga pada je nis gas hasil de komposisi minyak.

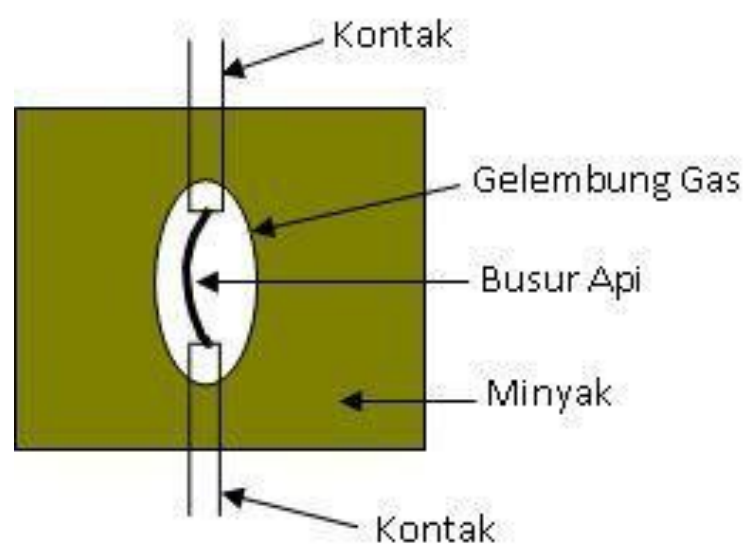

Gambar 1. Pemadaman busur api pada pemutus daya minyak

Gas yang timbul karena dekomposisi minyak menimbulkan tekanan terhadap minyak, sehingga minyak terdorong ke bawah melalui leher bilik. Di leher bilik, minyakini melakukan kontak yang intim dengan busur api. Hal ini akan menimbulkan pendinginan busur api, mendorong proses rekombinasi dan menjauhkan partikel bermuatan dari lintasan busur api. Minyak yang berada diantara kontak sangat efektif memutuskan arus. Kelemahannya adalah minyak mudah terbakar dan kekentalan minyak memperlambat pemisahan kontak, sehingga tidak cocok untuk sistem yang membutuhkan pemutusan arus yang cepat.

\section{PMT udara hembus}

PMT dengan udara hembus, adalah PMT yang dilengkapi dengan penghembus udara, yang diguakan untuk menghembus busur api, sampai bususr api padam, sehingga tidak menyebabkan kerusakan. PMT udara hembus dapat digunakan untuk memutus arus sampai dengan $40 \mathrm{KA}$ dan pada tangkaian bertegangan $765 \mathrm{KV}$, PMT udara hembus dirancang untuk mengatasi kelemahan PMT ,minyak, yaitu dengan membuat media isolator kontak dari bahan yang tidak mudah terbakar dan tidak menghalangi pemisahan kontak sehingga pemisahan kontak dapat dilaksanakan dalam waktu yang sangat cepat. Saat busur api timbul, udara tekanan tinggi dihembuskan ke busur api melalui nozle pada kontak pemisah dan ionisasi media diantara kontak dipadamkan oleh hembusan udara 
tekanan tinggi itu dan juga menyingkirkan partikel-partikel bermuatan dari sela kontak, udara ini juga berfungsiuntuk mencegah restriking voltage.(tegangan pukul ulang).

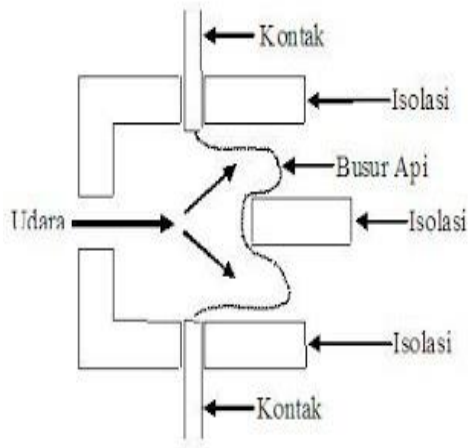

Gambar 2. Pemadaman busur api pada pemutusdaya udara hembus

Kontak pemutus ditempatkan didalam isolator, dan juga katup hembusan udara. Pada sakelar PMT kapasitas kecil, isolator ini merupakan satu kesatuan dengan PMT, tetapi untuk kapasitasbesartidakdemikianhalnya.

\section{PMT vakum}

PMT Vakum adalah PMT yang dilengkapi dengan penghisap busur api. Prinsip kerjanya apabila terrjadi busur api, maka busur api akan terhisap oleh lata vakum tersebut, sehingga busur api tidak menyebabkan kerusakan. PMT Vakum dapat digunakan sampai tegangan $38 \mathrm{KV}$, dimana kontak ditempatkan pada suatu biik vakum. Untuk mencagah udara masuk ke dalam bilik, maka bilik ini harus ditutup rapat dan kontak bergeraknya diikat ketat dengan perapat logam.

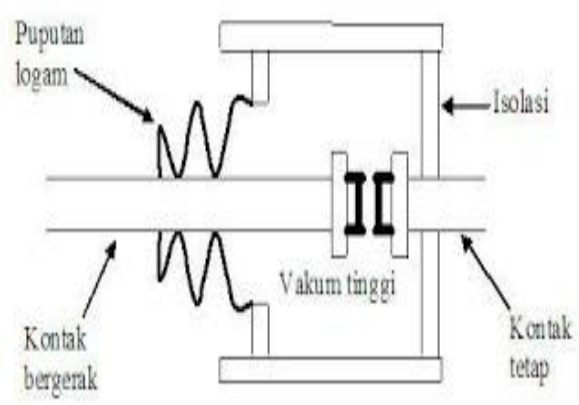

Gambar 3. Kontak pemutus daya vakum

\section{PMT dengan gas SF6}

PMT dengan media isolasi Gas dapat digunakan untuk memutus arus sampai $40 \mathrm{kA}$ pada rangkaian bertegangan sampai $765 \mathrm{kV}$. Media gas yang digunakan pada tipe ini adalah gas SF6 (Sulphur hexafluoride). Sifat gas SF6 murni adalah tidak berwarna, tidak berbau, tidak beracun dan tidak mudah terbakar. Pada suhu diatas $150^{\circ}$ C, gas SF6 mempunyai sifat tidak merusak metal, plastik dan bermacam bahan yang umumnya digunakan dalam pemutus tenaga tegangan tinggi. Sifat lain dari gas SF6 adalah mampu mengembalikan kekuatan dielektrik dengan cepat, tidak terjadi karbon selama terjadi busur api dan tidak menimbulkan bunyi pada saat pemutus tenaga menutup atau membuka. ( Yulistiawan et al., 2012).

\section{Proses Terjadinya Busur Api}

Pada waktu terjadi pemutusan atau penghubungan suatu rangkaian sistem penyaluran tenaga listrik maka akan terjadi gesekan antara kontak-kontak yang akan lepas atau berhubungan. Akibat adanya beda tegangan antara kontak-kontak tersebut, maka akan menimbulkan medan listrik. terlebih lagi karena beda tegangan yang tinggi, sehingga munculah busur api. Terjadinya busur api, diperlihatkan pada gambar 4.

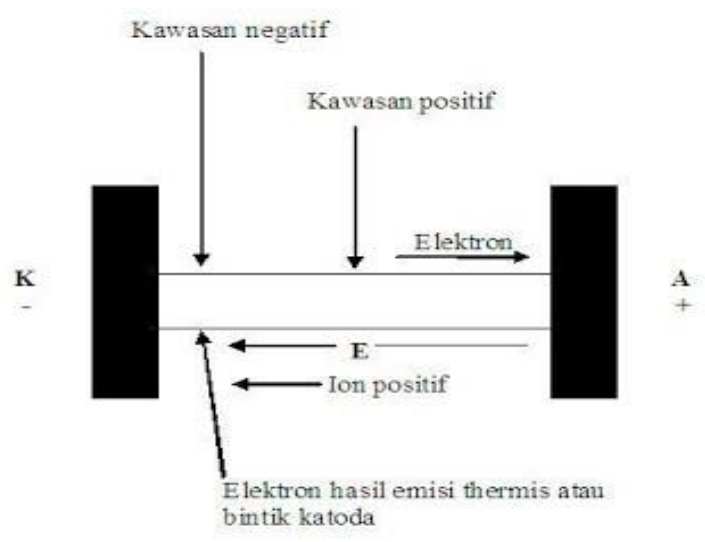

Gambar 4. Terjadinya busur api

Arus yang sebelumnya mengalir pada kontak akan memanaskan kontak dan menghasilkan emisi thermis pada permukaan kontak, sedangkan medan elektrik menimbulkan 
emisi medan tinggi pada kontak katoda (K). Kedua emisi ini menghasilkan elektron bebas yang sangat banyak dan bergerak menuju kontak anoda (A). Elektron-elektron ini membentur molekul netral media isolasi di kawasan positif, benturan-benturan ini akan menimbulkan proses ionisasi dikawasan positif, benturan-benturan ini akan menimbulkan proses ionisasi. Dengan demikianjjulah elektron bebas yang menuju anoda akan semakin bertambah dan muncul ion positif hasil ionisasi yang bergerak menuju katoda, perpindahan elektron bebas ke anoda menimbulkan arus dan memanaskan kontak anoda. Kion positif yang tiba di kontak katoda akan menimbulkan dua effek yang berbeda. Jika kontak terbuat dari bahan yang titik leburnya tinggi, misalnya tungsten atau karbon, maka ion positif akan menimbulkan pemanasan di katoda, akibatnya emisi thermis semakin meningkat. Jika kontak terbuat dari bahan yang titik leburnya rendah, misalnya tembaga, ion positif akan menimbulkan emisi medan yang tinggi. Hasil emisi thermis ini dan emisi medan tinggi akan melanggengkan proses ionisasi, sehingga perpindahan muatan antar kontak terus berlangsung dan inilah yang disebut busur api. Jika pengurangan partikel bermuatan karena proses deionisasi lebih banyak daripada penambahan muatan karena proses ionisasi, maka busur api akan padam. Ketika busur api padam, di sela kontak akan tetap ada terpaan medan elektrik. Jika suatu saat terjadi terpaan medan elektrik yang lebih besar daripada kekuatan dielektrik media isolasi kontak, maka busurapiakanterjadilagi (Guntoro, 2013).

\section{Cara kerja pemutus tenaga (PMT) dengan media Gas SF6.}

Gas SF6 memiliki sifat tidak berwarna, tidak berbau, tidak berracun dan tidak mudah terbakar. Pada temperatur diatas $150^{\circ} \mathrm{C}$ gas SF6 mempunyai sifat tidak merusak metal, plastik dan bermacam-macam bahan yang umumnya digunakan dalam pemutus tenaga tegangan tinggi. Sebagai isolasi listrik, gas SF6 mempunyai kekuatan dielektrik yang tinggi (2 - 3 kali dari udara) dan kekuatan dielektrik ini bertambah dengan pertambahan tekanan. Sifat lain dari gas SF6 ialah mampu mengembalikan kekuatan dielektrik dengan cepat, setelah arus bunga api listrik melalui titik nol. Pada PMT tipe tekanan tunggal, diisi gas SF6 dengan tekanan kira-kira 5 $\mathrm{Kg} / \mathrm{cm} 2$. Selama pemisahan kontak-kontak, gas SF6 ditekan kedalam suatu tabung atau silinder yang menempel pada kontak bergerak. Pada waktu pemutusan gas SF6 ditekan melalui nozzle dan tiupan ini yang memadamkan busur api. Pada tipe tekanan ganda, gas dari sistem tekanan tinggi dialirkan melalui nozzle ke gas sistem tekanan rendah selama pemadaman busur api. Pada tipe tekanan tinggi tekanan gas kurang lebih $12 \mathrm{Kg} / \mathrm{cm}$ dan pada sistem gas tekanan rendah tekanan gas kurang tekanan tinggi. ( Burhanulloh, 2017)

\section{DAMPAK GAS SF6}

\section{Terhadap Manusia}

- Pencemaran Gas SF6 adalah mengandung racun yang berakibat pada kulit,mata dan dapat merusak selaput lendir dan bila terpegang lama akan menggangu pangkal tenggorokan dan gangguan paru-paru, hati dan peredaran napas terhenti seperti pingsan.

- Dengan suatu konsentrasi SF6 melebihi 35\% volume dalam udara itu berbahaya dan dapat berakibat mati lemas kekurangan Oxigen

\section{Terhadap Peralatan}

Dalam kurun waktu yang tertentu akan terjadi pengapuran pada Kontak-kontak metalik dan terjadi pegumpalan berupa serbuk.

\section{KELEBIHAN DAN KEKURAGAN GAS SF 6}

\section{Kelebihan :}

1. Pengurangan sejumlah pemutus dalam hubungan seri per phasa pada rating tegangan yang digunakan.

2. Karena waktu durasi yang pendek dari busur api, maka bunga api kontak yang terjadi dibatasi meskipun untuk arus hubung singkat yang sangat tinggi.

3. Hasil busur api yang kebanyakan terdiri dari serbuk dengan sifat isolasi yang baik dapat dipindahkan saat perbaikan.

4. Gas blast tidak di-discharge (pelepasan muatan) ke atmosfir sehingga saat bekerja akan lebih tenang jika dibandingkan dengan Air Blast Breaker. 
5. Memiliki sifat kimia yang lamban, stabil, tidak mudah terbakar dan tidak beracun.

6. Pemutus dari gas SF6 mempunyai dimensi yang lebih jika dibandingkan dengan Air Blast Breaker.

\section{Kekurangan :}

1. Relatif lebih mahal dari segi pembiayaan.

2. Walaupun dalam jumlah yang kecil, apabila terjadi kerusakan maka membutuhkan waktu yang lama untuk perbaikan

3. Gas SF6 harus dipompa ke dalam tabung penyimpan apabila ada penelitian dan maintenance.

4. Karena titik lelehnya sangat rendah yaitu 100 Celcius dan tekanan $1,520 \mathrm{kN} / \mathrm{m} 2$, maka perlu dipakai alat pengukur suhu untuk pengontrolan (Elvansyah, 2016)

\section{KESIMPULAN}

Dengan pembahasan mengenai Gas SF6 di atas, maka penulis dapat menyimpulkan beberapa keseimpulan, diantaranya :

1. Gas SF6 merupakan bahan yang sangat baik untuk di gunakan pada peralatan tegangan tinggi karena gas SF6 memiliki kekuatan dielektrik $2 \frac{1}{2}$ sampai 3 kali dibanding udara.

2. Pada peralatan tegangan tinggi jika terjadi busur api maka gas SF6 dapat memadamkan busur api tersebut untuk menghindari kerusakan yang lebih parah.

3. Meskipun gas SF6 tidak berbau, berasa, dan berwarna, apabila gas tersebut lepas di udara bebas maka akan berbahaya bagi manusia, oleh karena itu gas SF6 jangan sampai tercemar/bocor ke udara bebas.
4. Untuk Decomposition Product yang dari penggunaan gas SF6 yang mengakibatkan berkurangnya kemurnian gas tersebut, sehingga berpotensi untuk berkurangnya kemampuan isolasi tegangan terhadap ground, maka dapat di lakukan penyaringan pada gas tersebut, untuk mengembalikan kondisi kemurnian gas SF6 pada kondisi prima dan siap digunakan kembali pada peralatan tegangan tinggi.

\section{DAFTAR PUSTAKA}

Adieliveline. 2013. Gas Insulated Switchgear SF6. https://adieliveline.wordpress.com/2013/10/0 7/gas-insulated-switchgear-sf6, diunduh :20 Januari 2017, jam : 13.30 WIB.

Burhanulloh. 2017. Cara kerja Pemutus Tenaga (PMT) dengan media gas SF6 pada tegangan 500 KV di PT.PLN P3B Jawa Bali UPT Jakarta Timur. Jakarta : Universitas Gunadarma.

Guntoro, H. 2013. Pemeliharaan PMTdi Cikarang Listrindo. Jakarta : Universitas Mercu Buana.

Elvansyah, M.R. 2016. Pemutus rangkaian yang menggunakan gas SF6 sebagai sarana pemadam busur api. Banjarmasin:Politeknik Negeri Banjarmasin.

PT. PLN. 1993. Buku Petunjuk Operasi \& Pemeliharaan Peralatan Untuk Pemutus Tenaga. Jakarta : PT PLN Pembangkitan dan Penyaluran Jawa bagian barat.

Yulistiawan, Hasan, B., Hasbullah. 2012. Gas SF6 merupakan salah satu media isolasi yang baik, dapat sampai temperatur $500^{\circ} \mathrm{C}$. Electrans, 11(2) 